\title{
Review Article \\ CD1-Restricted T Cells at the Crossroad of Innate and Adaptive Immunity
}

\author{
Catia S. Pereira ${ }^{1,2}$ and M. Fatima Macedo ${ }^{1,2,3}$ \\ ${ }^{1}$ Instituto de Investigação e Inovação em Saúde, Universidade do Porto, Porto, Portugal \\ ${ }^{2}$ Instituto de Biologia Molecular e Celular (IBMC), Universidade do Porto, Porto, Portugal
}

${ }^{3}$ Departamento de Ciências Médicas, Universidade de Aveiro, Aveiro, Portugal

Correspondence should be addressed to M. Fatima Macedo; fmacedo@ibmc.up.pt

Received 8 August 2016; Accepted 13 November 2016

Academic Editor: Mikhail M. Dikov

Copyright (C) 2016 C. S. Pereira and M. F. Macedo. This is an open access article distributed under the Creative Commons Attribution License, which permits unrestricted use, distribution, and reproduction in any medium, provided the original work is properly cited.

\begin{abstract}
Lipid-specific T cells comprise a group of T cells that recognize lipids bound to the MHC class I-like CD1 molecules. There are four isoforms of CD1 that are expressed at the surface of antigen presenting cells and therefore capable of presenting lipid antigens: $\mathrm{CD} 1 \mathrm{a}, \mathrm{CD} 1 \mathrm{~b}, \mathrm{CD} 1 \mathrm{c}$, and CD1d. Each one of these isoforms has distinct structural features and cellular localizations, which promotes binding to a broad range of different types of lipids. Lipid antigens originate from either self-tissues or foreign sources, such as bacteria, fungus, or plants and their recognition by CD1-restricted $\mathrm{T}$ cells has important implications in infection but also in cancer and autoimmunity. In this review, we describe the characteristics of CD1 molecules and CD1-restricted lipid-specific T cells, highlighting the innate-like and adaptive-like features of different CD1-restricted T cell subtypes.
\end{abstract}

\section{Introduction}

CD1-restricted $\mathrm{T}$ cells recognize lipid antigens bound to MHC class I-like CD1 molecules. The first paper describing CD1-restricted T cells was published in 1989, but the nature of the antigen presented was not identified [1]. The emergence of lipids as $\mathrm{T}$ cell antigens presented by CD1 molecules was only established 5 years later by the discovery of the antigenic properties of mycolic acid [2]. Nowadays, a variety of lipids, from both self- or non-self-origin, are known to bind $\mathrm{CD} 1$ molecules and to participate in lipid-specific $\mathrm{T}$ cell development and activation.

CD1-restricted $\mathrm{T}$ cells comprise specialized subtypes that participate in immune responses with innate-like and adaptive-like features. The relevance of these cells was described in the context of infection [3] and immune response against tumors [4]. Therefore, it has become pivotal to understand the properties of CD1 molecules, the mechanism of CD1-mediated lipid antigen presentation, and the biology of CD1-restricted T cells, to develop new strategies to control infection and cancer.

\section{CD1 Molecules}

Human CD1 molecules are encoded by 5 different genes localized to chromosome 1 . These genes encode 5 different CD1 isoforms: CD1a-CD1e. The functional CD1 molecules are heterodimers composed by association of CD1 with $\beta 2$ microglobulin. Based on sequence homology, CD1 isoforms can be classified into three groups. Group I is composed by $\mathrm{CDla}, \mathrm{CD} 1 \mathrm{~b}$, and CD1c isoforms, group II by CD1d, and group III by CDle.

2.1. Expression. Group I CD1 molecules are almost only expressed on thymocytes and dendritic cells (DCs) and are present in humans but not in mice or rats. CDla is also expressed on Langerhans cells and CD1c in a subset of B cells [5]. CD1d has a wide expression pattern and is present in both hematopoietic and nonhematopoietic derived cells. CD1d is highly expressed on cortical thymocytes, but it gets downregulated in medullary thymocytes. In peripheral blood, B cells, monocytes, DCs, and activated T cells express CD1d. CD1d is also expressed in the gut, liver, bile duct epithelium, pancreas, 

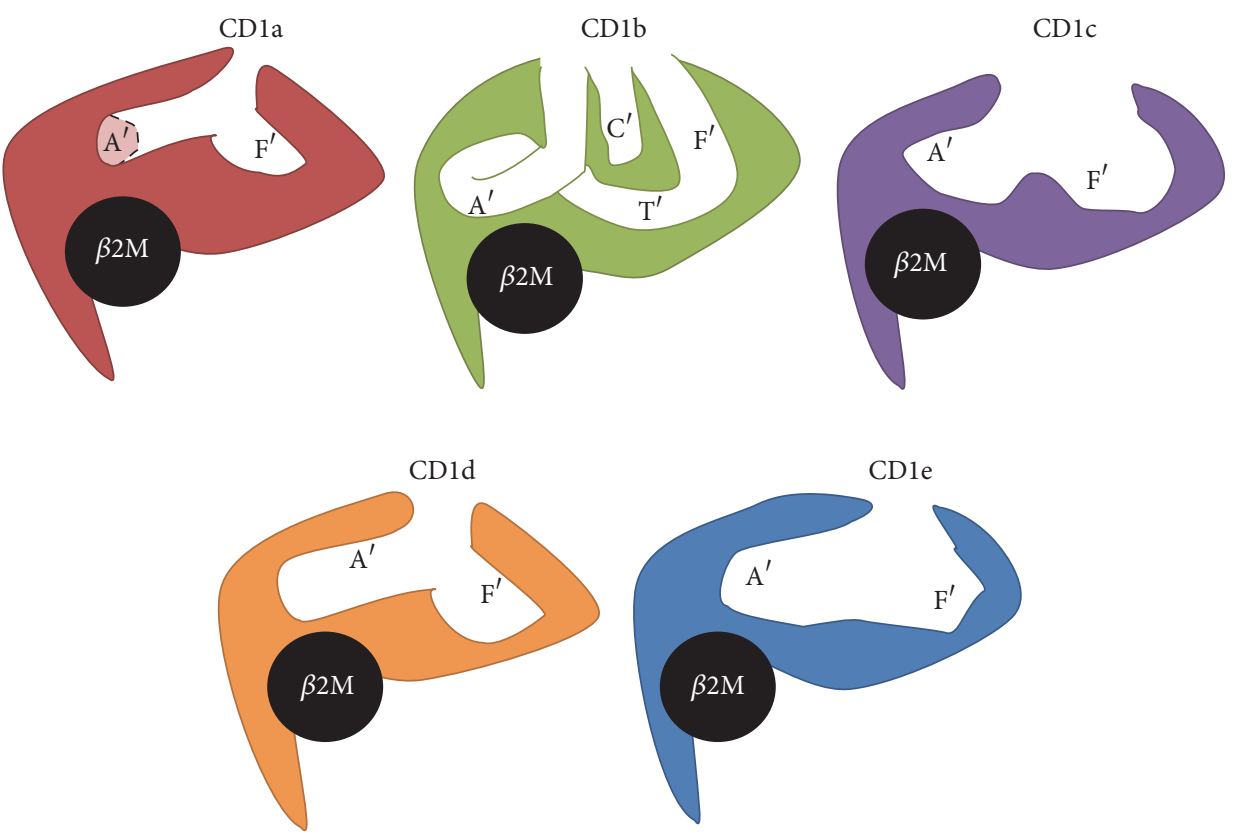

FIGURE 1: Schematic representation of the binding pockets from the different CD1 molecules (cross-sectional view). Dashed light colored area in $\mathrm{CD} 1 \mathrm{a}$ represents the terminus of the $\mathrm{A}^{\prime}$ pocket. $\beta 2 \mathrm{M}$ : $\beta 2$-microglobulin.

kidney, endometrium, testis, epididymis, conjunctiva, breast, and skin [5]. In the human gut, intestinal epithelial cells express and present antigens by CD1d [5]. More recently, adipocytes were also found to express CD1d and a role in lipid antigen presentation has been suggested [6, 7]. CDle is expressed on DCs but does not function as an antigen presenting molecule, since it is not present at the plasma membrane. This molecule functions as a lipid transfer protein (LTP) [8].

2.2. Structural Features. CD1 shares many structural features with MHC class I molecules. All CD1 isoforms are composed by a heavy chain that contains three extracellular domains $(\alpha 1, \alpha 2$, and $\alpha 3)$, a transmembrane domain, and an intracellular tail. The $\alpha 1$ and $\alpha 2$ extracellular domains are composed by two antiparallel $\alpha$-helices on the top of $6 \beta$-strands. These are supported by the $\alpha 3$ domain that interacts with $\beta 2$-microglobulin (the light chain) creating a heterodimer [9]. The striking difference between CD1 and MHC class I molecules relies on the antigen binding pockets. Contrary to MHC class I, CD1 pockets are lined by hydrophobic residues that interact with the hydrophobic part of the lipids while leaving the polar moieties exposed for TCR recognition [9]. The size, shape, and number of the pockets vary between CD1 isoforms, allowing the accommodation of lipids with variable fatty acid chain length (Figure 1) [10].

Similarly to MHC class I, CD1 molecules possess two deep pockets: $\mathrm{A}^{\prime}$ and $\mathrm{F}^{\prime}$. CD1b has two additional pockets, $\mathrm{C}^{\prime}$ and $\mathrm{T}^{\prime}$ that allow the binding of lipids with larger hydrophobic chains [11]. CD1a has the smallest binding groove and, contrarily to what is observed in the other CD1 isoforms, its $\mathrm{A}^{\prime}$ pocket is not directly connected to the other pockets, but instead it abruptly ends deep in the binding groove, functioning as a "molecular ruler" that prevents the binding of long hydrophobic chains (Figure 1) [12]. The $\mathrm{F}^{\prime}$ pocket is more permissive and allows binding of lipopeptides [13]. CDla also has a semi-open conformation that facilitates the loading of lipids at neutral $\mathrm{pH}$ and without the action of LTP [12, 14]. CD1b has the larger binding site, composed of four pockets, three of which are interconnected to form a large $\mathrm{A}^{\prime} \mathrm{T}^{\prime} \mathrm{F}^{\prime}$ super channel. This characteristic confers CD1b the unique ability to bind long-chain mycolyl lipids [15]. The acidic $\mathrm{pH}$ of the lysosomes allows relaxation of CD1b, which improves lipid binding [16]. Similarly to CD1a, CD1c has an $\mathrm{F}^{\prime}$ pocket that is permissive to lipopeptide binding and usually associates with antigens that only have one alkyl chain, suggesting that the $\mathrm{A}^{\prime}$ pocket might be occupied by spacer lipids that stabilize CD1c structure [17]. CD1d was crystallized in complex with several lipids [18-21]. In all glycosphingolipids containing a ceramide backbone, the sphingosine chain binds the $\mathrm{F}^{\prime}$ pocket while the fatty acid occupies the $A^{\prime}$ pocket, exposing the sugar head to the TCR. Despite its inability to present lipid antigens, the CD1e structure also contains $\mathrm{A}^{\prime}$ and $\mathrm{F}^{\prime}$ pockets, although they are not clearly separated, thus creating a larger groove [22]. Also, CDle has a solvent exposed groove. These two characteristics together allow quick binding and release of different types of lipids, compatible with CDle function of LTP [22].

2.3. Synthesis and Trafficking. After translation, CD1 molecules initiate their maturation process in the endoplasmic reticulum (ER). In the ER, glycosylation allows the binding of calnexin, calreticulin, and thiol oxidoreductase ERp57 that promote correct folding and assembly with $\beta 2$-microglobulin [23]. Another ER protein with a pivotal role in CD1 assembly 


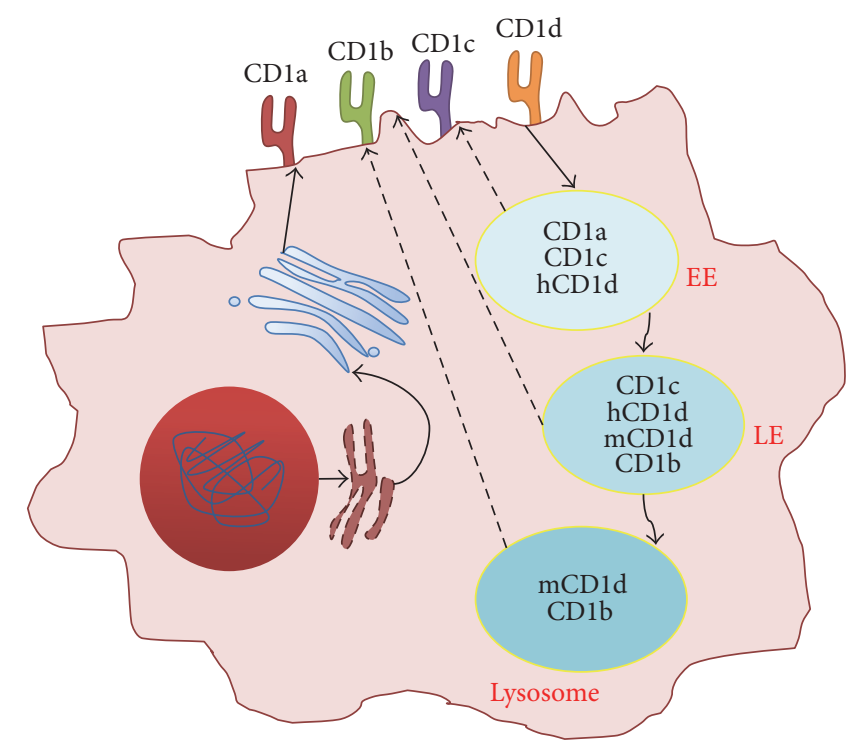

FIGURE 2: The cellular trafficking of CD1 molecules. After synthesis, CD1 molecules associate with $\beta 2$-microglobulin in the endoplasmic reticulum. Then, they traffic to the trans-Golgi network, where they are glycosylated and follow to the plasma membrane (solid arrows). There, CD1 molecules are internalized by the endocytic pathway, where most of the loading occurs. The different CD1 isoforms localize in different endocytic compartments. The loaded CD1 molecules then traffic to the plasma membrane, where they activate T cells (dashed arrows). EE: early endosome; LE: late endosome; hCD1d: human CD1d; mCD1d: mouse CD1d.

is microsomal triglyceride transfer protein (MTP). Absence of MTP results in severe defects in lipid antigen presentation by group I and group II CD1 isoforms [24-26]. The analysis of soluble CD1 molecules revealed that, during assembly, they are associated with different lipids rather than having empty pockets. Thus, it was suggested that MTP could load ER lipids into these pockets, stabilizing the molecules $[26,27]$. However, another report showed that MTP absence does not alter the biosynthesis, glycosylation maturation, or plasma membrane internalization of CD1 molecules, but it is important for the recycling from the lysosome to the cell surface, suggesting another function for MTP besides CD1 stabilization through lipid loading [28].

CD1 molecules continue their maturation in the transGolgi network (Figure 2). The identification of some Golgisynthesized lipids bound to CD1 suggests that they are loaded along the secretory pathway, after exiting the ER [29]. In the trans-Golgi network, CD1 molecules also complete their glycosylation process before being exposed at the cell surface. When in the plasma membrane, CD1 molecules are recycled through the endosomal route, where they encounter lipid antigens (Figure 2). Internalization of CD1b, CD1c, and CD1d is mediated by interaction of the cytoplasmic tail with the adaptor protein complex- (AP-) 2, which sorts cargo proteins into clathrin-coated pits [30-33]. Contrarily, CDla does not interact with AP-2 and is internalized using clathrin and dynamin-independent pathways [34]. After internalization into sorting endosomes, the different $\mathrm{CD} 1$ isoforms have distinct fates (Figure 2). CDla and CD1c localize in the endocytic recycling compartment, which indicates that they follow the slow recycling pathway back to the plasma membrane. However, CD1c can also be found in late endosomes. CD1b and mouse CD1d (mCD1d) interact with AP-3, which sorts these molecules to the late endosomes and lysosomes. Curiously, human CD1d does not interact with AP-3 and can be found in late endosomes [35]. Studies with mCDld lacking the cytoplasmic tail (and therefore not internalized for recycling) revealed the presence of mCD1d molecules in lysosomes, suggesting the existence of an alternative pathway that directly sorts mCD1d to lysosomes [36]. This was explained by the association of $\mathrm{mCD} 1 \mathrm{~d}$ with the invariant chain (Ii) and MHC class II in the ER, which directly sends mCDld to MHC class II compartments or lysosomes [37]. Later, Ii was also shown to associate with $\mathrm{CD1}$, suggesting that this might be applicable to all CD1 isoforms [38]. After reaching the endocytic compartments, CD1 molecules exchange the nonimmunogenic lipids acquired during assembly with antigenic lipids, with the help of several LTP. The mechanisms responsible for the targeting of CD1 molecules from the lysosome to the plasma membrane are not well understood, but it is known that localization of these molecules in lipid rafts improves antigen presentation [39]. Recently, it was shown that lysosomal $\mathrm{pH}$ had an influence on CD1d localization at the plasma membrane [40].

2.4. CD1-Binding Lipids. Lipid antigens include mostly phospholipids and sphingolipids (Table 1). Interestingly, sphingolipids are the only lipids shown to be presented by all CD1 isoforms, so far. However, a variety of lipid classes were shown to bind some $\mathrm{CD} 1$ isoforms and activate CD1-restricted T cells (Table 1). Curiously, some antigens can be presented by more than one $\mathrm{CD} 1$ isoform. The most striking example is sulfatide that has the unique property of binding and activating $\mathrm{T}$ cells restricted to all CD1 isoforms [14]. 
TABLE 1: Naturally occurring antigens for CD1-restricted T cells.

\begin{tabular}{|c|c|c|c|c|}
\hline Class & Lipid & Origin & $\mathrm{CD1}$ & References \\
\hline \multirow{8}{*}{ Phospholipids } & $\mathrm{PE}$ & Cypress; self & CD1a; mCD1d & {$[41,42]$} \\
\hline & $\mathrm{PC}$ & Cypress; self & CD1a; hCD1d; CD1c & {$[41,43]$} \\
\hline & PG & $\begin{array}{l}\text { M. tuberculosis; } L \text {. } \\
\text { monocytogenes; E. coli; C. } \\
\text { glutamicum Self }\end{array}$ & CD1b; mCD1d & {$[42,44-46]$} \\
\hline & PI & M. tuberculosis; self & mCD1d & {$[42,46]$} \\
\hline & Cardiolipin & Self & mCD1d & [18] \\
\hline & $\mathrm{DPG}$ & $\begin{array}{l}\text { M. tuberculosis; } L . \\
\text { monocytogenes }\end{array}$ & mCD1d & {$[45,46]$} \\
\hline & Lyso-PE & Self & $\mathrm{m} / \mathrm{hCD} 1 \mathrm{~d}$ & {$[47]$} \\
\hline & Lyso-PC & Self & m/hCD1d; CD1a & {$[47-49]$} \\
\hline Sphingolipids & Lyso-Sph & Self & hCD1d & [49] \\
\hline \multirow{11}{*}{ Glycosphingolipids } & Sulfatide & Self & CD1a; CD1b; CD1c; m/hCD1d & {$[14,50]$} \\
\hline & Lysosulfatide & Self & mCD1d & {$[50]$} \\
\hline & GM1 & Self & $\mathrm{CD} 1 \mathrm{~b}$ & [51] \\
\hline & GD3 & Self & $\mathrm{mCD} 1 \mathrm{~d}$ & {$[52]$} \\
\hline & $\alpha$-GalCer & Self & $\mathrm{m} / \mathrm{hCD} 1 \mathrm{~d}$ & {$[53]$} \\
\hline & $\beta$-GlcCer & Self & mCD1d & {$[54]$} \\
\hline & Lyso-GalCer & Self & mCD1d & {$[54]$} \\
\hline & $\beta$-GlcSph & Self & $\mathrm{m} / \mathrm{hCD} 1 \mathrm{~d}$ & {$[54,55]$} \\
\hline & $\beta$-GalCer & Self & mCD1d & {$[54]$} \\
\hline & iGb3 & Self & mCD1d & {$[56]$} \\
\hline & GSL-1 & Sphingomonas spp. & $\mathrm{m} / \mathrm{hCD} 1 \mathrm{~d}$ & [57] \\
\hline \multirow{3}{*}{ Plasmalogens } & pLPE & Self & $\mathrm{m} / \mathrm{hCD} 1 \mathrm{~d}$ & {$[58]$} \\
\hline & mLPA & Self & CD1c & {$[59]$} \\
\hline & eLPA & Self & mCD1d & {$[58]$} \\
\hline Oils & Triacylglyceride & Self & CDla & {$[60]$} \\
\hline Terpenes & Squalene & Self & CD1a & {$[60]$} \\
\hline Diacylglycerolipids & GalDAG & B. burgdorferi & $\mathrm{m} / \mathrm{hCD} 1 \mathrm{~d}$ & {$[61]$} \\
\hline \multirow{2}{*}{ Mycolates } & GMM & M. tuberculosis & CD1b & {$[62]$} \\
\hline & Mycolic acid & M. tuberculosis & $\mathrm{CD} 1 \mathrm{~b}$ & {$[2]$} \\
\hline \multirow{3}{*}{ Lipoglycans } & PIM & M. tuberculosis & CD1b & {$[63]$} \\
\hline & LAM & M. tuberculosis & $\mathrm{CD} 1 \mathrm{~b}$ & {$[63]$} \\
\hline & LPG & L. donovani & mCD1d & {$[64]$} \\
\hline Lipopeptides & Dideoximycobactin & M. tuberculosis & CD1a & {$[65]$} \\
\hline \multirow{2}{*}{ Mycoketides } & MPM & M. tuberculosis & CD1c & {$[66,67]$} \\
\hline & PM & M. tuberculosis & $\mathrm{CD} 1 \mathrm{c}$ & [66] \\
\hline
\end{tabular}

PE: phosphoethanolamine; PC: phosphatidylcholine; PG: phosphatidylglycerol; PI: phosphatidylinositol; DPG: diphosphatidylglycerol; Sph: sphingomyelin; GalCer: galactosylceramide; GlcCer: glucosylceramide; GlcSph: glucosylsphingosine; iGb3: isoglobotriaosylceramide; GSL-1: glycosphingolipid 1; pLPE: lysophosphatidylethanolamine; mLPA: methyl-lysophosphatidic acid; eLPA: lysophosphatidic acid; GalDag: galactosyldiacylglycerol; GMM: glucose monomycolate; PIM: phosphatidylinositol mannose; LAM: lipoarabinomannan; LPG: lipophosphoglycan; MPM: mannosyl phosphomycoketide; PM: phosphomycoketide.

Not all CD1-binding lipids are immunogenic. Another important group of CD1 binding lipids is spacer lipids. CD1 isoforms typically bind lipids with hydrophobic chains that match the size of the binding groove, suggesting a $1: 1$ stoichiometry. However, CDIb was found to be associated with rather small lipids that do not fully occupy the binding pocket. This raised the question of whether CDlb was able to bind two lipids simultaneously. Crystallography analysis of CD1b structure and lipidomics analysis of CD1b eluted lipids identified, besides the antigenic lipid, several spacer lipids that stabilize the CD1b molecule and that rearranged upon binding to allow antigen recognition [68]. Evidence from crystallographic studies also suggests the presence of spacer lipids in CD1a, CD1c, and CD1d [19, 66, 69]. 
Among nonimmunogenic CD1-binding lipids, we can also find molecules with inhibitory properties. The glycosphingolipid globotriaosylceramide was shown to bind CD1d and inhibit the activation of a subset of CD1d-restricted $\mathrm{T}$ cells, the invariant Natural Killer T (iNKT) cells [70]. The inhibition is achieved through a direct competition between globotriaosylceramide and iNKT cell antigens for CD1d binding. It is possible that this inhibitory characteristic is shared by other CD1 binding lipids that are not recognized by a TCR, thus representing an important mechanism for controlling the activation of lipid-specific T cells.

2.5. Lipid Loading on CD1 Molecules. Lipids are hydrophobic and therefore need assistance for transport, uptake, and processing. This role is played by LTPs. In the bloodstream, lipids travel in very low density or high density lipoprotein particles or associated with some monomeric proteins [13]. The uptake of the lipid antigens by the cells occurs by interaction with cellular receptors such as low density lipoprotein receptors and scavenger receptors. The receptor usage seems to be dependent on the type of cell and influenced by the lipid structure $[13,71,72]$. Lipid structure also influences intracellular trafficking. While lipid antigens with short unsaturated alkyl chains localize in the endocytic recycling compartment, lipids with long saturated tails travel to the late endocytic compartments [13]. This difference in trafficking allows the encounter of the different $\mathrm{CD} 1$ isoforms with their preferred ligands.

In endocytic compartments, specialized LTPs assist lipid binding to CD1. Although some self-lipids are loaded into CD1 during folding in the ER, exogenous lipids need to be loaded from membranes or lipid-protein complexes, once internalized. The lysosomal proteins that facilitate this process include saposins, GM2 activator protein, NiemannPick C2 (NPC2) protein, and CD1e [8, 73-81]. Saposins are a group of 4 proteins that arise due to cleavage of a common precursor: prosaposin. They were shown to be important for endogenous and exogenous lipid removal and loading into mouse and human CDId, both in the steady-state and during infection [75-77, 81]. Saposin B greatly improves human CDld-mediated lipid antigen presentation, but saposins A and $\mathrm{C}$ were also shown to efficiently perform lipid exchange in mCD1d molecules [75, 76, 81]. Saposin C binds both CD1b and CD1c, facilitating lipid loading in these molecules [73, 74]. Importantly, this function is restricted to lipid exchange, meaning that saposins are not capable of removing lipids from CD1 if they cannot be replaced by another. GM2 activator protein is a cofactor for $\beta$-hexosaminidase $\mathrm{A}$ but it also removes mCD1d bound-lipids, without the need of binding other lipids [81]. A similar function was found for the NPC2 protein [78]. CD1e was described as an isoform incapable of presenting lipid antigens, due to its absence from the plasma membrane. However, the endosomal localization and the similarities in the binding pocket shared by the different CD1 isoforms suggested that CD1e binds lipid antigens. In 2005, the role of CDle in lipid antigen processing was demonstrated by the identification of CDle as a cofactor for $\alpha$-mannosidase, a lysosomal enzyme that in the presence of CDle degrades complex nonimmunogenic mycobacterial lipids to antigenic forms [8]. Importantly, CDle promotes the loading and unloading of lipids into CD1d [80] and also influences lipid presentation by CD1b and CDlc [80].

Besides LTP, CD1 lipid exchange in endosomal compartments is also facilitated by the low $\mathrm{pH}$ that induces relaxation of the $\mathrm{CD} 1$ structure, promoting a more dynamic binding and dissociation of lipids [16, 71].

\section{CD1-Restricted T Cells}

CD1-restricted $\mathrm{T}$ cells can be classified as restricted to group I CD1 molecules or to CD1d. CD1d-restricted T cells are also designated Natural Killer T (NKT) cells, because most of these cells share surface markers of NK and T cells. NKT cells are further divided into two subsets. Type I NKT cells, or iNKT cells, are characterized by the expression of a semiinvariant TCR (V $\alpha 24 \mathrm{~J} \alpha 18 \mathrm{~V} \beta 11$ in humans and $\mathrm{V} \alpha 14 \mathrm{~J} \alpha 18$ paired with a limited repertoire of $\mathrm{V} \beta$ chains in mice) and by the recognition of the lipid antigen $\alpha$-galactosylceramide $(\alpha$-GalCer) [82]. Type II NKT cells recognize a variety of lipid antigens and express variable TCRs, although with a bias towards some $\mathrm{V} \alpha$ and $\mathrm{V} \beta$ chains [82].

Group I CD1-restricted T cells are polyclonal and probably undergo clonal expansion at the periphery, after antigen encounter. This results in a delayed effector response, consistent with an adaptive-like immune response, similar to what is observed for MHC-restricted T cells [4]. iNKT cells differ from most $\mathrm{T}$ cells due to their innate-like functions. After expansion and maturation in the thymus, iNKT cells are capable of responding to innate signals, such as cytokine stimulation, within hours. However, they also respond to TCR engagement by specific antigens, thus standing in the middle of the innate and adaptive immune response.

3.1. Adaptive-Like Group I CD1-Restricted T Cells. To date, there is no specific method to identify all lipid-specific group I CD1-restricted T cells. However, studies analyzing selfreactive group I CD1-restricted $\mathrm{T}$ cells described a high frequency of these cells, similar to what is observed for autoreactive conventional T cells [83]. Furthermore, autoreactive group I CD1-restricted $\mathrm{T}$ cells are present in both umbilical cord blood and peripheral blood at similar frequencies [83]. They express mainly the marker CD45RA, but a decrease of CD45RA-positive cells is seen in peripheral blood when compared with umbilical cord blood, consistent with an adaptive-like phenotype [83]. Also in accordance with the adaptive-like phenotype of these cells, the presence of Mycobacterium tuberculosis-specific CD1b-restricted T cells is dependent on previous contact with M. tuberculosis [84].

Upon activation, group I CD1-restricted T cells present a Th 0 or Th1 phenotype, producing large amounts of IFN $-\gamma$ and TFN- $\alpha$. They can also display cytotoxic activity and induce the lysis of intracellular mycobacteria [83-85].

CDla-restricted $\mathrm{T}$ cells are among the most frequent self-reactive CD1-restricted T cells in peripheral blood [83, 86]. Moreover, they are common in the skin. Skin CDlarestricted $\mathrm{T}$ cells become activated when in contact with CDla expressed by Langerhans cells. Upon activation, they produce IFN- $\gamma$, IL-2, and IL-22, a cytokine with suspected roles in skin immunity [86]. CDla-restricted $\mathrm{T}$ cells are unique in the 
way that their TCR can directly recognize the CD1a molecule without corecognition of a lipid antigen [48]. Self-ligands for CDla can be either permissive, such as lysophosphatidylcholine that allows activation of autoreactive $\mathrm{T}$ cells as it allows the contact of the CDla with the TCR, or nonpermissive, such as sphingomyelin that disrupts the TCR-CDla contact zone and in this way does not allow activation of CDlarestricted T cells [48]. Nevertheless, some CD1a-restricted T cell clones were shown to recognize antigens protruding out of the CDla pocket, such as sulfatide $[12,14]$, indicating that some TCRs require a lipid antigen for recognition.

The number of CD1b-restricted self-reactive $\mathrm{T}$ cells in blood is very low $[83,86]$. CD1b-restricted T cells seem to be especially important in mycobacterial immunity [84, 8789]. More recently, lipids from Staphylococcus aureus, Brucella melitensis, and Salmonella Typhimurium were shown to activate CD1b-restricted T cells [44]. Interestingly, these cells also displayed autoreactivity, indicating that bacteria and mammalian cells share CD1b antigens.

The frequency of CD1c-autoreactive T cells is not consensual in the literature $[83,86]$, with one study reporting a very low frequency [86] and a second study reporting an intermediated frequency between the high frequent CD1a autoreactive $\mathrm{T}$ cells and the low frequent CD1b and CD1d autoreactive T cells [83]. Although CD1c is widely expressed in DCs and B cells from peripheral blood, only sulfatide and mLPA were identified as self-antigens presented by CD1c (Table 1) [14, 59]. Similarly to what was observed for other CD1-restricted $\mathrm{T}$ cells, mycobacterial lipids induce CD1cdependent $\mathrm{T}$ cell responses (Table 1) [66].

3.2. Innate-Like CD1-Restricted T Cells: iNKT Cells. iNKT cells are easily identified by staining with CD1d tetramers loaded with $\alpha$-GalCer or with antibodies against the semiinvariant TCR. Thus, these are the most studied lipid-specific T cells. iNKT cell frequency varies between mice and humans. In mice, iNKT cells are more frequent in the liver and adipose tissue and are present at a lower percentage in thymus, spleen, bone marrow, peripheral blood, and lymph nodes. In humans, iNKT cells are more frequent in the adipose tissue, followed by the liver, and appear at lower percentages in spleen, peripheral blood, lymph nodes, bone marrow, and thymus [90].

An important feature of iNKT cells is related to their ability to quickly produce large amounts of cytokines upon stimulation, either by a TCR-dependent or independent manner [91]. This innate-like phenotype of iNKT cells is further demonstrated by the expression of CD45RO in humans and CD44 in mice and the early activation marker CD69 [82, 92]. Furthermore, iNKT cells display high autoreactivity. To date, the mechanisms that allow the control of iNKT cell autoreactivity are not completely understood. However, it has been shown that some self-lipids are capable of inhibiting iNKT cell activation and therefore may function as limiters of iNKT cell activation $[70,93]$.

The development of iNKT cells starts in the thymus by interactions of CD1d loaded with self-antigens, expressed in double-positive (DP) thymocytes, with DP thymocytes expressing the semi-invariant TCR [13]. This interaction ultimately leads to the expression of the transcription factor PLZF and iNKT cell maturation. In mice, iNKT cells express different types of transcription factors that drive them to NKT1, NKT2, or NKT17 subsets (Table 2).

NKT1 cells express mainly IFN- $\gamma$, high levels of T-bet, and low levels of GATA3. They are also characterized by NK1.1 expression, absence of IL-17RB, and dependence on IL-15 [94]. During differentiation, these cells downregulate PLZF [95].

NKT2 cells produce mainly IL- 4 and are characterized by the expression of the transcription factor GATA-3 [94, 95]. They are localized mainly in the lung and are more frequent in BALB/c mice. Contrary to NKT1 cells, NKT2 cells are dependent on IL-17RB expression for development and express high levels of PLZF [95]. In humans, the functional properties of CD4+ iNKT cells are highly associated with the NKT2 phenotype [96-98].

The NKT17 subset is characterized by the preferential production of IL-17 and IL-22, instead of IL- 4 and IFN- $\gamma$ [94]. They were identified within NK1.1- CD4- cells and are mainly present in the lung, lymph nodes, and skin $[99,100]$. Recently, they were shown to express syndecan1 [101]. Despite the fact that some IL-17 producing cells are committed to this fate in the thymus, iNKT cells can also acquire this ability in the periphery, under certain conditions [102]. At the transcriptional level, the development of NKT17 cells is repressed by ThPOK and driven by ROR $\gamma \mathrm{t}$ expression [103-105]. E protein was also shown to be important to drive subset commitment. Increased expression of this protein leads to a reduction in NKT1 cells with an increase in NKT2 and NKT17 cells [106].

So far, the existence of these subsets in humans was not clarified. Thus, in humans, iNKT cell subsets are still defined based on the expression of cell surface molecules (such as CD4 and CD8) and cytokine production. Contrary to what is observed in mice, iNKT cells in humans can express only CD4, only CD8, or none of the molecules. Importantly, CD 4 and CD8 expression defines functionally distinct subsets. CD4- iNKT cells (which include both CD8+ and double negative cells) are characterized by a Th0 phenotype, while CD4+ iNKT cells tend to produce larger amounts of Th2 cytokines [96-98, 107]. Among CD4-iNKT cells, those expressing CD8 present a Th1 bias, producing larger amounts of IFN- $\gamma$ and almost no IL-4, when compared to double negative cells [98]. They also display the highest cytotoxic activity [98]. Another subset is characterized by cells producing IL-17 that arise in response to proinflammatory conditions and express CD161 [108]. It is therefore necessary to analyze the different iNKT cell subsets in pathology, since their impact in disease may be different. Indeed, alterations in iNKT cell CD4+/CD4subsets were described in Fabry disease, a lysosomal storage disease characterized by accumulation of glycosphingolipids, despite the fact that a normal percentage of total iNKT cells was observed in the peripheral blood of patients [109-111].

3.3. Type II NKT Cells: A Mixed Population of Innate-Like and Adaptive-Like T Cells. Type II NKT cells are the most frequent CD1d-restricted T cells in humans but represent the minority in mice [112]. Contrary to iNKT cells, type II NKT 
TABLE 2: Main iNKT cell subsets in mice: transcriptional programs, surface markers, cytokine production, and frequency.

\begin{tabular}{|c|c|c|c|c|}
\hline & Transcriptional factors & Surface markers & Cytokine production & Frequency $^{*}$ \\
\hline \multirow{4}{*}{ NKT1 } & T-bet $^{\text {hi }}$ & NK1.1 & IFN- $\gamma$ & \multirow{4}{*}{ Most frequent subset } \\
\hline & GATA- $3^{\text {lo }}$ & ${\mathrm{IL}-17 \mathrm{RB}^{-}}^{-}$ & IL-4 & \\
\hline & $\mathrm{PLZF}^{-}$ & IL-15R $\alpha^{+}$ & & \\
\hline & $\mathrm{Id} 2^{+}$ & $\mathrm{CD}^{+/-}$ & & \\
\hline \multirow{4}{*}{ NKT2 } & T-bet ${ }^{\text {lo }}$ & NK1.1 $1^{-}$ & IL-4 & \multirow{4}{*}{ More common in the lung } \\
\hline & GATA- $3^{\text {hi }}$ & $\mathrm{IL}^{\mathrm{I}} 17 \mathrm{RB}^{+}$ & IL-13 & \\
\hline & PLZF $^{\text {high }}$ & $\mathrm{CD} 4^{+}$ & & \\
\hline & $\mathrm{Id}^{+}$ & & & \\
\hline \multirow{3}{*}{ NKT17 } & $\operatorname{ROR} \gamma \mathrm{t}^{+}$ & NK1.1 $1^{-}$ & IL-17 & \multirow{3}{*}{ Mainly present in the lung, lymph nodes, and skin } \\
\hline & PLZF $^{\text {int }}$ & ${\mathrm{IL}-17 \mathrm{RB}^{+}}^{+}$ & IL-22 & \\
\hline & & $\mathrm{CD} 4^{-}$ & & \\
\hline
\end{tabular}

* In C57BL/6 mice. hi: high; lo: low.

cells express diverse TCRs and respond to a variety of lipid antigens, of either self- or non-self-origin (Table 1). Thus, identifying the whole population of type II NKT cells is currently a challenge. Initially, the comparison of MHC-deficient mice (lacking conventional T cells) with MHC/CD1d double knockouts described a population of CD4+ non- $\alpha$-GalCer reactive $\mathrm{T}$ cells that displayed an effector memory phenotype and bias towards some autoreactive TCRs [113, 114].

More recently, using 4get mice (in which cells expressing IL-4 are GFP+) type II NKT cells were shown to constitutively express IL-4 [115]. Thus, these mice were crossed with $\mathrm{J} \alpha 18^{-/-}$, to obtain a model in which type II NKT cells are identified by GFP expression [115]. A polyclonal population that shares some developmental traits with iNKT cells was characterized. Deficiency of SAP and PLZF compromises the development of iNKT cells but also leads to decreases in type II NKT cell percentage [115]. Phenotypically, these polyclonal type II NKT cells are very similar to iNKT cells. They are characterized by an activated memory state, as determined by CD69 and CD44 expression. Regarding coreceptor expression, they can express only CD4 or neither CD4 nor CD8 [115]. However, they are distinct from iNKT cells when considering cytokine production. They produce less IL- 4 and less IFN- $\gamma$, but similar levels of IL-13 and GM-CSF [115]. Although polyclonal, type II NKT cells showed a bias towards the usage of TCR V $\beta$ 8.1/8.2 chains [115].

A different approach for the characterization of type II NKT cells relies in the use of CD1d tetramers loaded with lipid antigens. Staining of human PBMCs with sulfatide-loaded CDld tetramers revealed that most of sulfatide-reactive NKT cells possess $\gamma \delta$ TCRs, expressing the V $\delta 1$ segment [116]. Another report that characterized $\beta$-glucosylceramide and $\beta$ glucosylsphingosine-specific type II NKT cells showed that these cells could express CD4 or CD8 [55]. Furthermore, these cells can convert to a $\mathrm{T}$ follicular-helper phenotype upon injection of antigen and induce antibody production, germinal center formation, and the differentiation of $\mathrm{B}$ cells in plasmablasts, indicating a role in help to B cells, as previously described for iNKT cells [55]. Importantly, the $\beta$ glucosylceramide and $\beta$-glucosylsphingosine-specific type II
NKT cells identified in this study mainly expressed CD45RA, consistent with a naïve phenotype, instead of the effector memory phenotype previously described in mice [55].

Altogether, these studies suggest that type II NKT cells represent a heterogeneous group of CDld-restricted T cells, with cells that display an innate-like response similar to iNKT cells, but also with other cells, displaying adaptive-like immune functions. The relative contribution of the innatelike and adaptive-like cells for the overall group of type II NKT cells is still unclear.

\section{Concluding Remarks}

Lipid-specific CD1-restricted T cells comprise an important part of the immune system. However, the existent studies so far were not able to completely characterize and unequivocally include CD1-restricted $\mathrm{T}$ cells in the innate or adaptive immune responses. Instead, they stand at the crossroad of these responses and may have an important role in bridging the adaptive and the innate arms of the immune system. A complete characterization of lipid-specific CD1-restricted T cells is hampered by the lack of specific markers to identify the different CD1-restricted T cell populations. Hence, most of the information available on these cells arose from the study of individual T cell clones. Although valuable, this information may not be representative of the in vivo dynamics. In the past few years, great progresses were made in this field, mainly due to the development of CD1 tetramers loaded with lipid antigens. Using CD1 tetramers, it is possible to analyze lipid-specific CD1-restricted T cells ex vivo and to phenotypically and functionally characterize them. Lipid antigens were shown to be present in cancer cells and infectious agents, and therefore the complete knowledge of these cells is important to develop new strategies against cancer and infectious diseases.

\section{Competing Interests}

The authors declare that there is no conflict of interests regarding the publication of this paper. 


\section{Acknowledgments}

Financial support was given by Norte Portugal Regional Operational Programme (NORTE 2020), under the PORTUGAL 2020 Partnership Agreement, through the European Regional Development Fund (ERDF) (Norte-01-0145FEDER-000012). Catia S. Pereira was supported by Fundao para a Cincia e a Tecnologia (SFRH/BD/79211/2011).

\section{References}

[1] S. Porcelli, M. B. Brenner, J. L. Greenstein, S. P. Balk, C. Terhorst, and P. A. Bleicher, "Recognition of cluster of differentiation 1 antigens by human $\mathrm{CD} 4^{-} \mathrm{CD} 8^{-}$cytolytic T lymphocyte," Nature, vol. 341, no. 6241, pp. 447-450, 1989.

[2] E. M. Beckman, S. A. Porcelli, C. T. Morita, S. M. Behar, S. T. Furlong, and M. B. Brenner, "Recognition of a lipid antigen by CD1-restricted $\alpha \beta^{+}$T cells," Nature, vol. 372, no. 6507, pp. 691694, 1994.

[3] G. De Libero and L. Mori, "The T-cell response to lipid antigens of Mycobacterium tuberculosis," Frontiers in Immunology, vol. 5, article 219, p. 1, 2014.

[4] L. Mori, M. Lepore, and G. De Libero, "The immunology of CD1- and MR1-restricted T cells," Annual Review of Immunology, vol. 34, no. 1, pp. 479-510, 2016.

[5] S. K. Dougan, A. Kaser, and R. S. Blumberg, "CD1 expression on antigen-presenting cells," Current Topics in Microbiology and Immunology, vol. 314, pp. 113-141, 2007.

[6] M. Rakhshandehroo, S. M. W. Gijzel, R. Siersbæk et al., "CD1d-mediated presentation of endogenous lipid antigens by adipocytes requires microsomal triglyceride transfer protein," The Journal of Biological Chemistry, vol. 289, no. 32, pp. 2212822139, 2014.

[7] J. Y. Huh, J. I. Kim, Y. J. Park et al., "A novel function of adipocytes in lipid antigen presentation to iNKT cells," Molecular and Cellular Biology, vol. 33, no. 2, pp. 328-339, 2013.

[8] H. De La Salle, S. Mariotti, C. Angenieux et al., "Assistance of microbial glycolipid antigen processing by CD1e," Science, vol. 310, no. 5752, pp. 1321-1324, 2005.

[9] D. Ly and D. B. Moody, "The CD1 size problem: lipid antigens, ligands, and scaffolds," Cellular and Molecular Life Sciences, vol. 71, no. 16, pp. 3069-3079, 2014.

[10] L. Mori and G. De Libero, "T cells specific for lipid antigens," Immunologic Research, vol. 53, no. 1-3, pp. 191-199, 2012.

[11] T. Batuwangala, D. Shepherd, S. D. Gadola et al., "The crystal structure of human CD1b with a bound bacterial glycolipid," The Journal of Immunology, vol. 172, no. 4, pp. 2382-2388, 2004.

[12] D. M. Zajonc, M. A. Elsliger, L. Teyton, and I. A. Wilson, "Crystal structure of CDla in complex with a sulfatide self antigen at a resolution of $2.15 \AA$," Nature Immunology, vol. 4, no. 8, pp. 808-815, 2003.

[13] M. Salio, J. D. Silk, E. Yvonne Jones, and V. Cerundolo, "Biology of CD1- and MR1-restricted T cells," Annual Review of Immunology, vol. 32, pp. 323-366, 2014.

[14] A. Shamshiev, H.-J. Gober, A. Donda, Z. Mazorra, L. Mori, and G. De Libero, "Presentation of the same glycolipid by different CD1 molecules," Journal of Experimental Medicine, vol. 195, no. 8, pp. 1013-1021, 2002.

[15] T.-Y. Cheng, M. Relloso, I. Van Rhijn et al., "Role of lipid trimming and CD1 groove size in cellular antigen presentation," EMBO Journal, vol. 25, no. 13, pp. 2989-2999, 2006.
[16] M. Relloso, T.-Y. Cheng, J. S. Im et al., "pH-Dependent interdomain tethers of CD1b regulate its antigen capture," Immunity, vol. 28, no. 6, pp. 774-786, 2008.

[17] L. Scharf, N. S. Li, A. J. Hawk et al., "The 2.5 a structure of CD1c in complex with a mycobacterial lipid reveals an open groove ideally suited for diverse antigen presentation," Immunity, vol. 33, no. 6, pp. 853-862, 2010.

[18] M. Dieudé, H. Striegl, A. J. Tyznik et al., "Cardiolipin binds to CD1d and stimulates CD1d-restricted $\gamma \delta$ T cells in the normal murine repertoire," Journal of Immunology, vol. 186, no. 8, pp. 4771-4781, 2011.

[19] K. S. Wun, G. Cameron, O. Patel et al., "A molecular basis for the exquisite CD1d-restricted antigen specificity and functional responses of natural killer T cells," Immunity, vol. 34, no. 3, pp. 327-339, 2011.

[20] E. D. Yu, E. Girardi, J. Wang et al., "Structural basis for the recognition of C20:2- $\alpha \mathrm{GalCer}$ by the invariant natural killer T cell receptor-like antibody L363," Journal of Biological Chemistry, vol. 287, no. 2, pp. 1269-1278, 2012.

[21] T. Mallevaey, A. J. Clarke, J. P. Scott-Browne et al., "A molecular basis for NKT cell recognition of CD1d-self-antigen," Immunity, vol. 34, no. 3, pp. 315-326, 2011.

[22] L. F. Garcia-Alles, G. Giacometti, C. Versluis et al., "Crystal structure of human CDle reveals a groove suited for lipidexchange processes," Proceedings of the National Academy of Sciences of the United States of America, vol. 108, no. 32, pp. 1323013235, 2011.

[23] S.-J. Kang and P. Cresswell, "Calnexin, calreticulin, and ERp57 cooperate in disulfide bond formation in human CD1d heavy chain," The Journal of Biological Chemistry, vol. 277, no. 47, pp. 44838-44844, 2002.

[24] S. Zeissig, S. K. Dougan, D. C. Barral et al., "Primary deficiency of microsomal triglyceride transfer protein in human abetalipoproteinemia is associated with loss of CD1 function," The Journal of Clinical Investigation, vol. 120, no. 8, pp. 2889-2899, 2010.

[25] A. Kaser, D. L. Hava, S. K. Dougan et al., "Microsomal triglyceride transfer protein regulates endogenous and exogenous antigen presentation by group $1 \mathrm{CD} 1$ molecules," European Journal of Immunology, vol. 38, no. 8, pp. 2351-2359, 2008.

[26] S. K. Dougan, A. Salas, P. Rava et al., "Microsomal triglyceride transfer protein lipidation and control of CD1d on antigenpresenting cells," The Journal of Experimental Medicine, vol. 202, no. 4, pp. 529-539, 2005.

[27] S. Brozovic, T. Nagaishi, M. Yoshida et al., "CD1d function is regulated by microsomal triglyceride transfer protein," Nature Medicine, vol. 10, no. 5, pp. 535-539, 2004.

[28] Y. Sagiv, L. Bai, D. G. Wei et al., "A distal effect of microsomal triglyceride transfer protein deficiency on the lysosomal recycling of CD1d," Journal of Experimental Medicine, vol. 204, no. 4, pp. 921-928, 2007.

[29] D. Cox, L. Fox, R. Tian et al., "Determination of cellular lipids bound to human CD1d molecules," PLoS ONE, vol. 4, no. 5, Article ID 0005325, 2009.

[30] V. Briken, R. M. Jackman, S. Dasgupta, S. Hoening, and S. A. Porcelli, "Intracellular trafficking pathway of newly synthesized CD1b molecules," The EMBO Journal, vol. 21, no. 4, pp. 825-834, 2002.

[31] M. Sugita, E. P. Grant, E. Van Donselaar et al., "Separate pathways for antigen presentation by CD1 molecules," Immunity, vol. 11, no. 6, pp. 743-752, 1999. 
[32] M. Sugita, N. van Der Wel, R. A. Rogers, P. J. Peters, and M. B. Brenner, "CD1c molecules broadly survey the endocytic system," Proceedings of the National Academy of Sciences of the United States of America, vol. 97, no. 15, pp. 8445-8450, 2000.

[33] M. Sugita, R. M. Jackman, E. Van Donselaar et al., "Cytoplasmic tail-dependent localization of CD1b antigen-presenting molecules to MIICs," Science, vol. 273, no. 5273, pp. 349-352, 1996.

[34] D. C. Barral, M. Cavallari, P. J. McCormick et al., "CD1a and MHC class I follow a similar endocytic recycling pathway," Traffic, vol. 9, no. 9, pp. 1446-1457, 2008.

[35] M. Sugita, X. Cao, G. F. M. Watts, R. A. Rogers, J. S. Bonifacino, and M. B. Brenner, "Failure of trafficking and antigen presentation by CD1 in AP-3-deficient cells," Immunity, vol. 16, no. 5, pp. 697-706, 2002.

[36] Y.-H. Chiu, S.-H. Park, K. Benlagha et al., "Multiple defects in antigen presentation and $\mathrm{T}$ cell development by mice expressing cytoplasmic tail-truncated CD1d," Nature Immunology, vol. 3, no. 1, pp. 55-60, 2002.

[37] J. Jayawardena-Wolf, K. Benlagha, Y.-H. Chiu, R. Mehr, and A. Bendelac, "CD1d endosomal trafficking is independently regulated by an intrinsic CDld-encoded tyrosine motif and by the invariant chain," Immunity, vol. 15, no. 6, pp. 897-908, 2001.

[38] I. Sloma, M.-T. Zilber, T. Vasselon et al., "Regulation of CD1a surface expression and antigen presentation by invariant chain and lipid rafts," The Journal of Immunology, vol. 180, no. 2, pp. 980-987, 2008.

[39] J. S. Im, P. Arora, G. Bricard et al., "Kinetics and cellular site of glycolipid loading control the outcome of natural killer T cell activation," Immunity, vol. 30, no. 6, pp. 888-898, 2009.

[40] P. Arora, S. S. Kharkwal, T. W. Ng et al., "Endocytic $\mathrm{pH}$ regulates cell surface localization of glycolipid antigen loaded CD1d complexes," Chemistry and Physics of Lipids, vol. 191, pp. 75-83, 2015.

[41] E. Agea, A. Russano, O. Bistoni et al., "Human CD1-restricted T cell recognition of lipids from pollens," The Journal of Experimental Medicine, vol. 202, no. 2, pp. 295-308, 2005.

[42] J. E. Gumperz, C. Roy, A. Makowska et al., "Murine CD1drestricted T cell recognition of cellular lipids," Immunity, vol. 12, no. 2, pp. 211-221, 2000.

[43] A. M. Russano, G. Bassotti, E. Agea et al., "CD1-restricted recognition of exogenous and self-lipid antigens by duodenal $\gamma \delta+\mathrm{T}$ lymphocytes," Journal of Immunology, vol. 178, no. 6, pp. 36203626, 2007.

[44] I. Van Rhijn, T. Van Berlo, T. Hilmenyuk et al., "Human autoreactive T cells recognize CD1b and phospholipids," Proceedings of the National Academy of Sciences of the United States of America, vol. 113, no. 2, pp. 380-385, 2016.

[45] B. J. Wolf, R. V. V. Tatituri, C. F. Almeida et al., "Identification of a potent microbial lipid antigen for diverse NKT cells," Journal of Immunology, vol. 195, no. 6, pp. 2540-2551, 2015.

[46] R. V. V. Tatituri, G. F. M. Watts, V. Bhowruth et al., "Recognition of microbial and mammalian phospholipid antigens by NKT cells with diverse TCRs," Proceedings of the National Academy of Sciences of the United States of America, vol. 110, no. 5, pp. 1827-1832, 2013.

[47] S. Zeissig, K. Murata, L. Sweet et al., "Hepatitis B virus-induced lipid alterations contribute to natural killer T cell-dependent protective immunity," Nature Medicine, vol. 18, no. 7, pp. 10601068, 2012.
[48] R. W. Birkinshaw, D. G. Pellicci, T.-Y. Cheng et al., “ $\alpha \beta$ T cell antigen receptor recognition of CDla presenting self lipid ligands," Nature Immunology, vol. 16, no. 3, pp. 258-266, 2015.

[49] L. M. Fox, D. G. Cox, J. L. Lockridge et al., "Recognition of lysophospholipids by human natural killer T lymphocytes," PLoS Biology, vol. 7, no. 10, Article ID e1000228, 2009.

[50] M. Blomqvist, S. Rhost, S. Teneberg et al., "Multiple tissuespecific isoforms of sulfatide activate CD1d-restricted type II NKT cells," European Journal of Immunology, vol. 39, no. 7, pp. 1726-1735, 2009.

[51] A. Shamshiev, A. Donda, T. I. Prigozy et al., "The $\alpha \beta$ T cell response to self-glycolipids shows a novel mechanism of CD1b loading and a requirement for complex oligosaccharides," Immunity, vol. 13, no. 2, pp. 255-264, 2000.

[52] J.-E. Park, D. Y. Wu, M. Prendes et al., "Fine specificity of natural killer T cells against GD3 ganglioside and identification of GM3 as an inhibitory natural killer T-cell ligand," Immunology, vol. 123, no. 1, pp. 145-155, 2008.

[53] L. Kain, B. Webb, B. L. Anderson et al., "The identification of the endogenous ligands of natural killer $t$ cells reveals the presence of mammalian $\alpha$-linked glycosylceramides," Immunity, vol. 41, no. 4, pp. 543-554, 2014.

[54] S. Rhost, L. Löfbom, B.-M. Rynmark et al., "Identification of novel glycolipid ligands activating a sulfatide-reactive, CD1drestricted, type II natural killer T lymphocyte," European Journal of Immunology, vol. 42, no. 11, pp. 2851-2860, 2012.

[55] S. Nair, C. S. Boddupalli, R. Verma et al., "Type II NKTTFH cells against Gaucher lipids regulate B-cell immunity and inflammation," Blood, vol. 125, no. 8, pp. 1256-1271, 2015.

[56] D. Zhou, J. Mattner, C. Cantu III et al., "Lysosomal glycosphingolipid recognition by NKT cells," Science, vol. 306, no. 5702, pp. 1786-1789, 2004.

[57] X. Long, S. Deng, J. Mattner et al., "Synthesis and evaluation of stimulatory properties of Sphingomonadaceae glycolipids," Nature Chemical Biology, vol. 3, no. 9, pp. 559-564, 2007.

[58] F. Facciotti, G. S. Ramanjaneyulu, M. Lepore et al., "Peroxisomederived lipids are self antigens that stimulate invariant natural killer T cells in the thymus," Nature Immunology, vol. 13, no. 5, pp. 474-480, 2012.

[59] M. Lepore, C. de Lalla, S. R. Gundimeda et al., "A novel selflipid antigen targets human T cells against CD1c+ leukemias," Journal of Experimental Medicine, vol. 211, no. 7, pp. 1363-1377, 2014.

[60] A. de Jong, T.-Y. Cheng, S. Huang et al., "CD1a-autoreactive T cells recognize natural skin oils that function as headless antigens," Nature Immunology, vol. 15, no. 2, pp. 177-185, 2014.

[61] Y. Kinjo, E. Tupin, D. Wu et al., "Natural killer T cells recognize diacylglycerol antigens from pathogenic bacteria," Nature Immunology, vol. 7, no. 9, pp. 978-986, 2006.

[62] D. B. Moody, B. B. Reinhold, M. R. Guy et al., "Structural requirements for glycolipid antigen recognition by CD1brestricted T cells," Science, vol. 278, no. 5336, pp. 283-286, 1997.

[63] P. A. Sieling, D. Chatterjee, S. A. Porcelli et al., "CD1-restricted T cell recognition of microbial lipoglycan antigens," Science, vol. 269, no. 5221, pp. 227-230, 1995.

[64] J. L. Amprey, J. S. Im, S. J. Turco et al., "A subset of liver NK T cells is activated during Leishmania donovani infection by CD1d-bound lipophosphoglycan," Journal of Experimental Medicine, vol. 200, no. 7, pp. 895-904, 2004.

[65] D. B. Moody, D. C. Young, T.-Y. Cheng et al., "T cell activation by lipopeptide antigens," Science, vol. 303, no. 5657, pp. 527-531, 2004. 
[66] D. Ly, A. G. Kasmar, T.-Y. Cheng et al., "CD1c tetramers detect ex vivo T cell responses to processed phosphomycoketide antigens," Journal of Experimental Medicine, vol. 210, no. 4, pp. 729741, 2013.

[67] D. B. Moody, T. Ulrichs, W. Mühlecker et al., "CD1c-mediated T-cell recognition of isoprenoid glycolipids in Mycobacterium tuberculosis infection," Nature, vol. 404, no. 6780, pp. 884-888, 2000.

[68] L. F. Garcia-Alles, A. Collmann, C. Versluis et al., "Structural reorganization of the antigen-binding groove of human $\mathrm{CD} 1 \mathrm{~b}$ for presentation of mycobacterial sulfoglycolipids," Proceedings of the National Academy of Sciences of the United States of America, vol. 108, no. 43, pp. 17755-17760, 2011.

[69] D. M. Zajonc, M. D. M. Crispin, T. A. Bowden et al., "Molecular mechanism of lipopeptide presentation by CDla," Immunity, vol. 22, no. 2, pp. 209-219, 2005.

[70] C. S. Pereira, C. Sa-Miranda, G. De Libero, L. Mori, and M. F. Macedo, "Globotriaosylceramide inhibits iNKT-cell activation in a CD1d-dependent manner," European Journal of Immunology, vol. 46, no. 1, pp. 147-153, 2016.

[71] G. De Libero and L. Mori, "Novel insights into lipid antigen presentation," Trends in Immunology, vol. 33, no. 3, pp. 103-111, 2012.

[72] S. Freigang, E. Landais, V. Zadorozhny et al., "Scavenger receptors target glycolipids for natural killer T cell activation," Journal of Clinical Investigation, vol. 122, no. 11, pp. 3943-3954, 2012.

[73] L. León, R. V. V. Tatituri, R. Grenha et al., "Saposins utilize two strategies for lipid transfer and CD1 antigen presentation," Proceedings of the National Academy of Sciences of the United States of America, vol. 109, no. 12, pp. 4357-4364, 2012.

[74] F. Winau, V. Schwierzeck, R. Hurwitz et al., "Saposin C is required for lipid presentation by human CD1b," Nature Immunology, vol. 5, no. 2, pp. 169-174, 2004.

[75] W. Yuan, X. Qi, P. Tsang et al., "Saposin B is the dominant saposin that facilitates lipid binding to human CD1d molecules," Proceedings of the National Academy of Sciences of the United States of America, vol. 104, no. 13, pp. 5551-5556, 2007.

[76] M. Salio, H. Ghadbane, O. Dushek et al., "Saposins modulate human invariant natural killer $\mathrm{t}$ cells self-Reactivity and facilitate lipid exchange with cdld molecules during antigen presentation," Proceedings of the National Academy of Sciences of the United States of America, vol. 110, no. 49, pp. E4753-E4761, 2013.

[77] S.-J. Kang and P. Cresswell, "Saposins facilitate CD1d-restricted presentation of an exogenous lipid antigen to T cells," Nature Immunology, vol. 5, no. 2, pp. 175-181, 2004.

[78] N. Schrantz, Y. Sagiv, Y. Liu, P. B. Savage, A. Bendelac, and L. Teyton, "The Niemann-Pick type C2 protein loads isoglobotrihexosylceramide onto CD1d molecules and contributes to the thymic selection of NKT cells," Journal of Experimental Medicine, vol. 204, no. 4, pp. 841-852, 2007.

[79] D. Cala-De Paepe, E. Layre, G. Giacometti et al., "Deciphering the role of CDle protein in mycobacterial phosphatidyl-myoinositol mannosides (PIM) processing for presentation by CD1b to T lymphocytes," Journal of Biological Chemistry, vol. 287, no. 37, pp. 31494-31502, 2012.

[80] F. Facciotti, M. Cavallari, C. Angénieux et al., "Fine tuning by human CDle of lipid-specific immune responses," Proceedings of the National Academy of Sciences of the United States of America, vol. 108, no. 34, pp. 14228-14233, 2011.
[81] D. Zhou, C. Cantu III, Y. Sagiv et al., "Editing of CD1d-bound lipid antigens by endosomal lipid transfer proteins," Science, vol. 303, no. 5657, pp. 523-527, 2004.

[82] D. I. Godfrey, S. Stankovic, and A. G. Baxter, "Raising the NKT cell family," Nature Immunology, vol. 11, no. 3, pp. 197-206, 2010.

[83] C. De Lalla, M. Lepore, F. M. Piccolo et al., "High-frequency and adaptive-like dynamics of human CD1 self-reactive T cells," European Journal of Immunology, vol. 41, no. 3, pp. 602-610, 2011.

[84] M. Gilleron, S. Stenger, Z. Mazorra et al., "Diacylated sulfoglycolipids are novel mycobacterial antigens stimulating CD1restricted T cells during infection with Mycobacterium tuberculosis," The Journal of Experimental Medicine, vol. 199, no. 5, pp. 649-659, 2004.

[85] T. Ulrichs, D. B. Moody, E. Grant, S. H. E. Kaufmann, and S. A. Porcelli, "T-cell responses to CD1-presented lipid antigens in humans with Mycobacterium tuberculosis infection," Infection and Immunity, vol. 71, no. 6, pp. 3076-3087, 2003.

[86] A. de Jong, V. Peña-Cruz, T.-Y. Cheng, R. A. Clark, I. Van Rhijn, and D. B. Moody, "CD1a-autoreactive T cells are a normal component of the human $\alpha \beta$ T cell repertoire," Nature Immunology, vol. 11, no. 12, pp. 1102-1109, 2010.

[87] A. G. Kasmar, I. van Rhijn, T.-Y. Cheng et al., "CD1b tetramers bind $\alpha \beta$ T cell receptors to identify a mycobacterial glycolipidreactive T cell repertoire in humans," Journal of Experimental Medicine, vol. 208, no. 9, pp. 1741-1747, 2011.

[88] I. Van Rhijn, A. Kasmar, A. De Jong et al., "A conserved human $\mathrm{T}$ cell population targets mycobacterial antigens presented by CD1b," Nature Immunology, vol. 14, no. 7, pp. 706-713, 2013.

[89] I. Van Rhijn, N. A. Gherardin, A. Kasmar et al., "TCR bias and affinity define two compartments of the CD1b-glycolipid- specific T cell repertoire," Journal of Immunology, vol. 192, no. 9, pp. 4054-4060, 2014.

[90] S. P. Berzins, M. J. Smyth, and A. G. Baxter, "Presumed guilty: natural killer T cell defects and human disease," Nature Reviews Immunology, vol. 11, no. 2, pp. 131-142, 2011.

[91] P. J. Brennan, M. Brigl, and M. B. Brenner, "Invariant natural killer T cells: an innate activation scheme linked to diverse effector functions," Nature Reviews Immunology, vol. 13, no. 2, pp. 101-117, 2013.

[92] C. J. Montoya, D. Pollard, J. Martinson et al., "Characterization of human invariant natural killer $\mathrm{T}$ subsets in health and disease using a novel invariant natural killer $\mathrm{T}$ cell-clonotypic monoclonal antibody, 6B11," Immunology, vol. 122, no. 1, pp. 114, 2007.

[93] M. Kanamori, Y. Tasumi, T. Iyoda, M. Ushida, and K. Inaba, "Sulfatide inhibits $\alpha$-galactosylceramide presentation by dendritic cells," International Immunology, vol. 24, no. 2, pp. 129136, 2012.

[94] E. Y. Kim, L. Lynch, P. J. Brennan, N. R. Cohen, and M. B. Brenner, "The transcriptional programs of iNKT cells," Seminars in Immunology, vol. 27, no. 1, pp. 26-32, 2015.

[95] M. G. Constantinides and A. Bendelac, "Transcriptional regulation of the NKT cell lineage," Current Opinion in Immunology, vol. 25, no. 2, pp. 161-167, 2013.

[96] P. T. Lee, K. Benlagha, L. Teyton, and A. Bendelac, "Distinct functional lineages of human V $\alpha 24$ natural killer T cells," Journal of Experimental Medicine, vol. 195, no. 5, pp. 637-641, 2002.

[97] J. E. Gumperz, S. Miyake, T. Yamamura, and M. B. Brenner, "Functionally distinct subsets of CD1d-restricted natural killer 
T cells revealed by CD1d tetramer staining," Journal of Experimental Medicine, vol. 195, no. 5, pp. 625-636, 2002.

[98] V. O’Reilly, S. G. Zeng, G. Bricard et al., "Distinct and overlapping effector functions of expanded human $\mathrm{CD} 4^{+}, \mathrm{CD}^{+} \mathrm{a}^{+}$and $\mathrm{CD} 4{ }^{-} \mathrm{CD} 8 \mathrm{a}^{-}$invariant natural killer T cells," PLoS ONE, vol. 6, no. 12, Article ID e28648, 2011.

[99] M.-L. Michel, A. C. Keller, C. Paget et al., "Identification of an IL-17-producing NK1.1 ${ }^{\text {neg }}$ iNKT cell population involved in airway neutrophilia," Journal of Experimental Medicine, vol. 204, no. 5, pp. 995-1001, 2007.

[100] J.-M. Doisne, C. Becourt, L. Amniai et al., "Skin and peripheral lymph node invariant NKT cells are mainly retinoic acid receptor-related orphan receptor $\gamma \mathrm{t}^{+}$and respond preferentially under inflammatory conditions," The Journal of Immunology, vol. 183, no. 3, pp. 2142-2149, 2009.

[101] H. Dai, A. Rahman, A. Saxena et al., "Syndecan-1 identifies and controls the frequency of IL-17-producing naïve natural killer T (NKT17) cells in mice," European Journal of Immunology, vol. 45, no. 11, pp. 3045-3051, 2015.

[102] M. Monteiro, C. F. Almeida, A. Agua-Doce, and L. Graca, "Induced IL-17-producing invariant NKT cells require activation in presence of TGF- $\beta$ and IL-1 $\beta$," The Journal of Immunology, vol. 190, no. 2, pp. 805-811, 2013.

[103] M.-L. Michel, D. Mendes-da-Cruz, A. C. Keller et al., "Critical role of ROR- $\gamma \mathrm{t}$ in a new thymic pathway leading to IL-17producing invariant NKT cell differentiation," Proceedings of the National Academy of Sciences of the United States of America, vol. 105, no. 50, pp. 19845-19850, 2008.

[104] A. Enders, S. Stankovic, C. Teh et al., "ZBTB7B (Th-POK) regulates the development of IL-17-producing CD1d-restricted mouse NKT cells," Journal of Immunology, vol. 189, no. 11, pp. 5240-5249, 2012.

[105] I. Engel, M. Zhao, D. Kappes, I. Taniuchi, and M. Kronenberg, "The transcription factor Th-POK negatively regulates Th17 differentiation in V $\alpha 14 i$ NKT cells," Blood, vol. 120, no. 23, pp. 4524-4532, 2012.

[106] T. Hu, H. Wang, A. Simmons et al., "Increased level of E protein activity during invariant NKT development promotes differentiation of invariant NKT2 and invariant NKT17 subsets," The Journal of Immunology, vol. 191, no. 10, pp. 5065-5073, 2013.

[107] T. Takahashi, S. Chiba, M. Nieda et al., "Cutting edge: analysis of human $\mathrm{V} \alpha 24^{+} \mathrm{CD}^{+}$NKT cells activated by $\alpha$-galactosylceramide-pulsed monocyte-derived dendritic cells," Journal of Immunology, vol. 168, no. 7, pp. 3140-3144, 2002.

[108] L. Moreira-Teixeira, M. Resende, M. Coffre et al., "Proinflammatory environment dictates the IL-17-producing capacity of human invariant NKT cells," Journal of Immunology, vol. 186, no. 10, pp. 5758-5765, 2011.

[109] A. Balreira, M. F. Macedo, C. Girão et al., "Anomalies in conventional $\mathrm{T}$ and invariant natural killer T-cell populations in Fabry mice but not in Fabry patients," British Journal of Haematology, vol. 143, no. 4, pp. 601-604, 2008.

[110] M. F. Macedo, R. Quinta, C. S. Pereira, and M. C. Sa Miranda, "Enzyme replacement therapy partially prevents invariant Natural Killer T cell deficiency in the Fabry disease mouse model," Molecular Genetics and Metabolism, vol. 106, no. 1, pp. 83-91, 2012.

[111] C. S. Pereira, O. Azevedo, M. L. Maia, A. F. Dias, C. SaMiranda, and M. F. Macedo, "Invariant natural killer T cells are phenotypically and functionally altered in Fabry disease," Molecular Genetics and Metabolism, vol. 108, no. 4, pp. 241-248, 2013.
[112] I. Marrero, R. Ware, and V. Kumar, "Type II NKT cells in inflammation, autoimmunity, microbial immunity, and cancer," Frontiers in Immunology, vol. 6, article 316, 2015.

[113] S. Cardell, S. Tangri, S. Chan, M. Kronenberg, C. Benoist, and D. Mathis, "CD1-restricted CD4+ T cells in major histocompatibility complex class II-deficient mice," Journal of Experimental Medicine, vol. 182, no. 4, pp. 993-1004, 1995.

[114] S.-H. Park, A. Weiss, K. Benlagha, T. Kyin, L. Teyton, and A. Bendelac, "The mouse CD1d-restricted repertoire is dominated by a few autoreactive T cell receptor families," Journal of Experimental Medicine, vol. 193, no. 8, pp. 893-904, 2001.

[115] J. Zhao, X. Weng, S. Bagchi, and C.-R. Wang, "Polyclonal type II natural killer T cells require PLZF and SAP for their development and contribute to CpG-mediated antitumor response," Proceedings of the National Academy of Sciences of the United States of America, vol. 111, no. 7, pp. 2674-2679, 2014.

[116] L. Bai, D. Picard, B. Anderson et al., "The majority of CD1dsulfatide-specific $\mathrm{T}$ cells in human blood use a semiinvariant V $\delta 1$ TCR," European Journal of Immunology, vol. 42, no. 9, pp. 2505-2510, 2012. 


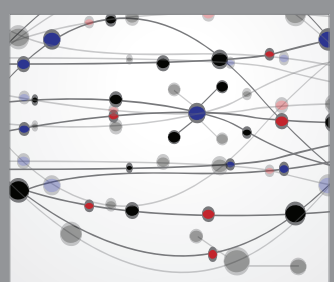

The Scientific World Journal
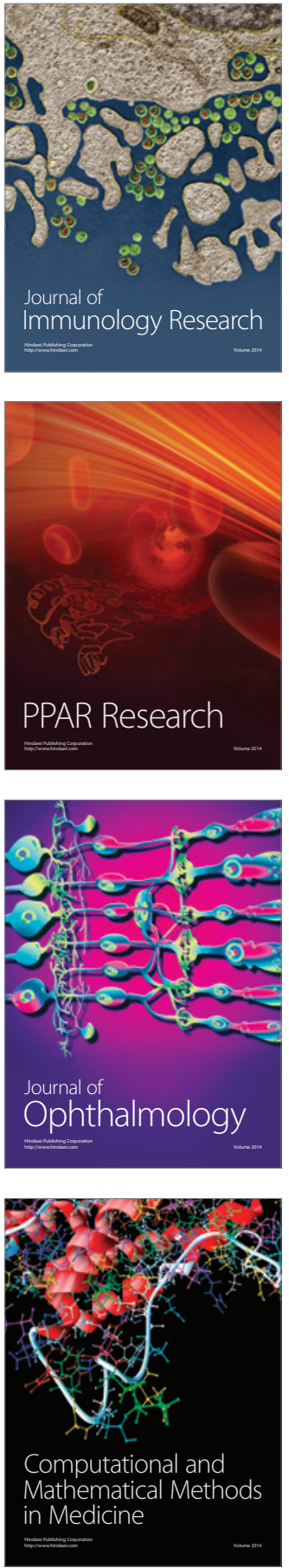

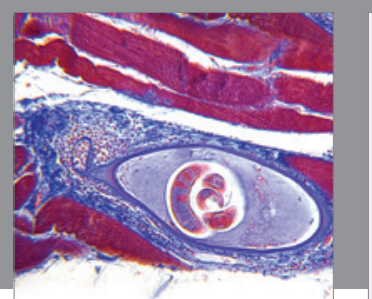

Gastroenterology Research and Practice

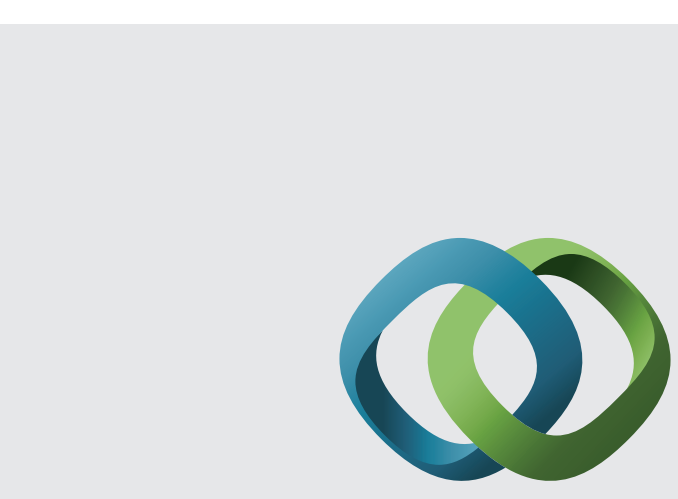

\section{Hindawi}

Submit your manuscripts at

http://www.hindawi.com
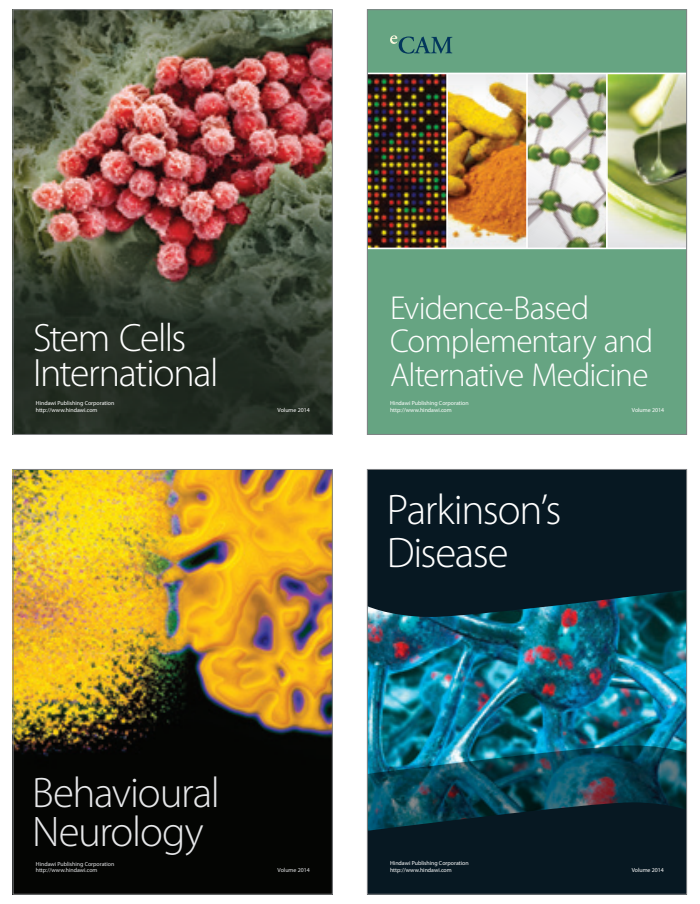
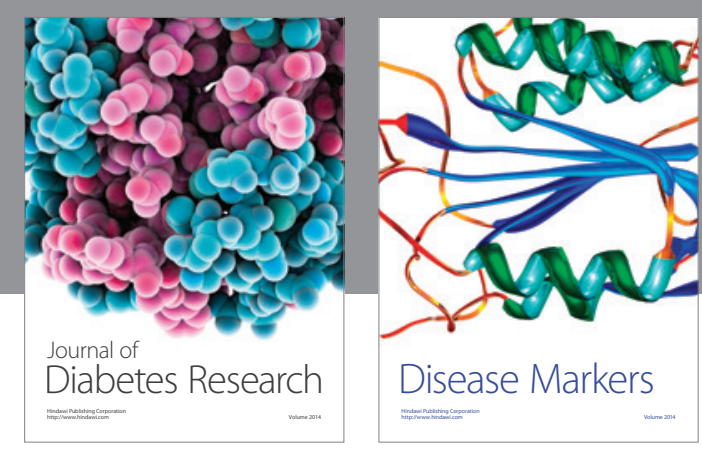

Disease Markers
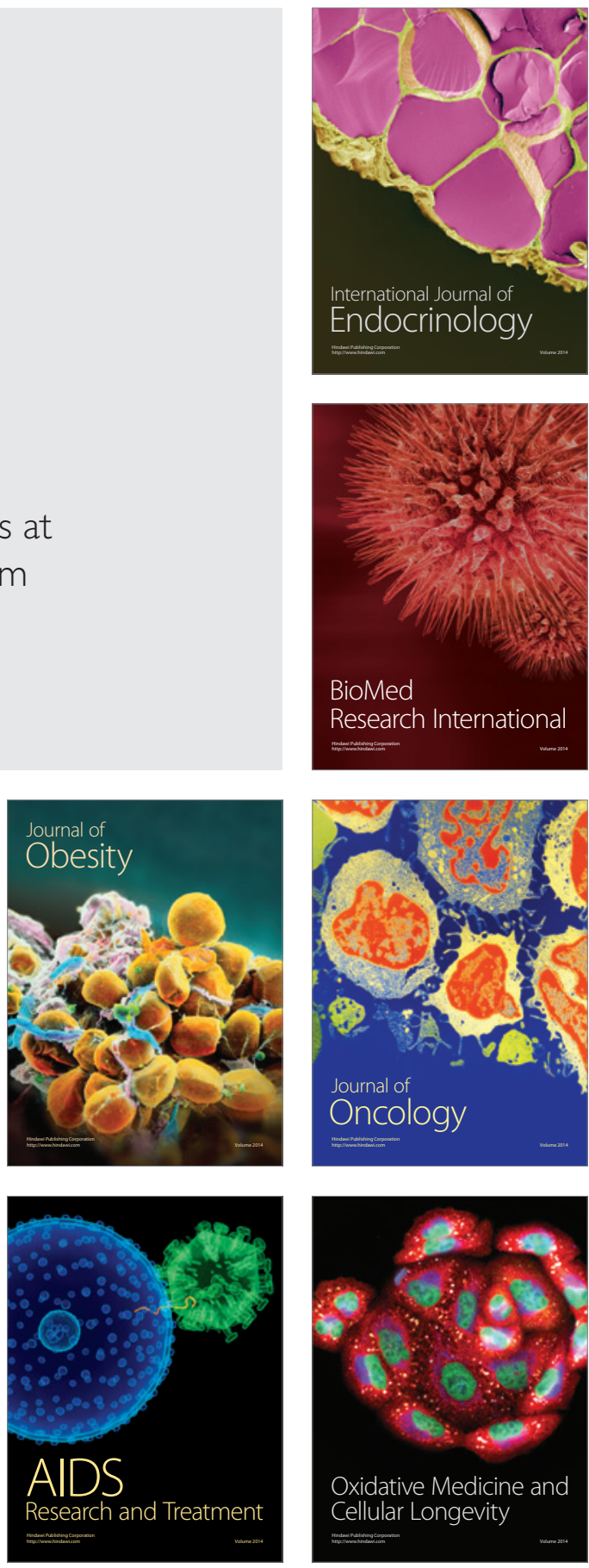